\title{
KONSEP DASAR PENDIDIKAN NAHDLATUL ULAMA KH. HASYIM ASY'ARI
}

\author{
Ahmad Ainun Najib \\ Konsentrasi Psikologi Pendidikan Islam, Program Studi Interdisciplinary Islamic \\ Studies, Fakultas Pascasarjana, Universitas Islam Negeri Sunan Kalijaga \\ Ahmadnajib186@gmail.com
}

\begin{abstract}
The concept of Nadhaltul Ulama's education did not escape the development of da'wah and the process of Islamic boarding schools in Java, in this case KH. Hasyim Asy'ari as the founder of the organization along with other kyiai took part in the education of Nahdlutul Ulama, Nahdhltul Ulama organizations which became the largest organizations in Indonesia at the beginning were categorized as traditionalists, as well as early translations made by KH. Hasyim Asy'ari, which began in Islamic boarding schools so as to renew the understanding of education both formal and informal through the basic concepts of epistemology and learning anology as well as methods in learning.
\end{abstract}

\section{Keywords: Learning, Nahdlutul Ulama}

\begin{abstract}
Abstrak
Konsep pendidikan Nadhaltul Ulama tidak luput dari perkembangan dakwah dan proses pondok pesantren yang ada di pulau Jawa dalam hal ini KH. Hasyim Asy'ari selaku pendidiri organisasi berserta para kyiai lainya ikut ambil dalam pendidikan Nahdlutul Ulama. Oraganisasi Nahdhatul ulama yang menjadi organisasi terbanyak di Indonesia pada mulanya di katergorikan dalam tradisionalis, serta awal konsep pendidikan dilakukan oleh KH. Hasyim Asy'ari yang bermula di pondok pesantren sehingga mengalami pembaharuan konsep pendidikan baik formal maupun nonformal yang melalui konsep dasar epistimologi dan Anologi pembelajaran serta metode dalam pemebelajaran.
\end{abstract}

\section{Kata Kunci : Pembelajaran, Nahdlatul Ulama}

\section{PENDAHULUAN}

Pada awal abad XX fenomena paling mencolok yang menunjukkan kebangkitan Bumi putra untuk melawan penjajah Belanda adalah banyaknya gerakan rakyat. Jika diklasifikasikan pergerakan tersebut berdasarkan 
ideologinya antara lain nasionalisme yang dipresentasikan oleh Budi Utomo dan Indische Partij, Komunisme yang dipresentasikan oleh Indische Sociaal Democratische Vereeniging (ISDV) dan PKI serta Islam yang dipresentasikan oleh Syarikat Islam, Muhammadiyah (1912), NU (1349/1926), ${ }^{1}$ Jami'at Khair (1905), Al Irsyad (1913), Persyarikatan Ulama (1911) dan Persatuan Islam (1923). ${ }^{2}$

Dari sekian banyak organisasi-organisasi tersebut yang masih eksis adalah NU salah satunya sebagai organisasi kemasyarakatan (ormas) Islam, Kelembagaan Agama Islam Departemen Agama, Sejarah Madrasah: Pertumbuhan, Dinamika, dan Perkembangannya di Indonesia Imroatul Fatihah dan yang paling banyak memiliki jamaah di Nusantara ini bahkan mungkin tidak berlebihan jika NU disebut sebagai Ormas Islam terbesar di dunia.

Gerakan NU lebih dikategorikan sebagai gerakan tradisional. Dan hal itu pun terproyeksikan tatkala NU mengarahkan gerakannya pada sektor pendidikan dengan memilih pesantren sebagai bentuk dan substansi pendidikan meskipun belakangan ini NU melakukan peningkatan, dalam arti positif, dengan berkeinginan memperluas pendidikan umum. ${ }^{3}$

\section{PEMBAHASAN}

\section{A. Lahirnya Nahdlatul Ulama}

Nahdlatul Ulama (NU) didirikan oleh KH. Hasyim Asy’ari (18711947), seorang ulama besar dari pesantren Tebuireng jombang jawa timur, pada tanggal 31 januari 1926 M. NU didirikan notabene oleh para ulama yang bergabung dalam Komite Hijaz. Para ulama sepakat mendirikan oeganisasi besarta namanya yang diserahkan amanat peresmiannya kepada KH. Hasyim Asy'ari setelah KH. Hasyim Asy'ari beristikharah. Buahnya kemudian KH.

\footnotetext{
${ }^{1} \mathrm{H}$ M Thoyyib, IM dan Endang Turmudzi, Islam Ahlussunnah Waljama'ah di Indonesia: Sejarah, Pemikiran dan Dinamikaa Nahdlatul Ulama, Cetakan kedua. (Jakarta: Pustaka Ma'arif, 2007). Hal. 205-206

${ }^{2}$ Direktorat Jenderal Kelembagaan Agama Islam Departemen Agama, Sejarah Madrasah: Pertumbuhan, Dinamika, dan Perkembangannya di Indonesia. (Jakarta: 2004). Hal.101107.

${ }^{3}$ A. Malik Fadjar, Reorientasi Pendidikan Islam. (Jakarta: Fajar Dunia, 1999). Hal.65-66.
} 
Hasyim Asy’ari mendapat kepercayaan dari gurunya, yakni KH. Mohammad Kholil. $^{4}$

Tujuan didirikannya organisasi NU adalah untuk mempertahankan praktek keagaamaan yang sudah mentradisi di Nusantara untuk mengimbangi gencarnya ekspansi pembaruan Islam. Karena itulah, gerakan NU dikenal memiliki ciri dengan membawa nilai kearifan lokal serta resistensi kuat untuk memeperthankan budaya pesantren. ${ }^{5}$

Pesantren nampaknya merupakan lembaga dakwah NU yang paling penting, dominan, dan tua sebagai tempat pengkajian Islam. Pesantren merupakan lembaga pendidikan Islam khas indonesia. Basis pesantren umumnya di daerah pedesaan, sehingga tidak mengherankan jika nilai-nilai tradisi yang dibangunnya sangat relevan dengan budaya masyarakat Islam pedesaan. nilai-nilai tradisi pesantren inilah yang sebenarnya merupakan salah satu substansi dalam menanaman nila-nilai ke-Islaman.

Benteng perlawanan terhadap golongan pembaharu yang didirikan kalangan tradisi di pulau Jawa berbentuk Nahdlatul Ulama. Didirakan dalam tahun 1926. Kehadiran dan kelahiran NU sebagai organisasi para ulama di tengah-tengah masyarakat yang plural dan majemuk seperti Indonesia bukan suatu kebetulan. Terdapat pilihan-pilihan logis dan sadar atas terbentuknya NU oleh para ulama tradisional waktu itu. Jika diteliti secara seksama, sejak kelahirannya, NU telah dihadapkan pada pertarungan ideologi yang ada sebelumnya. Tidak hanya ideologi keagamaan yang ada di tanah air, tetapi, dan ini yang lebih penting adalah ideologi yang "diimpor" dari Mesir dan Saudi Arabia.

Berbeda dengan ormas keagamaan lainnya, kehadiran NU merupakan bagian dari desakan local untuk merawat tradisi yang saat itu terancam oleh kalangan reformis atau modernis (baca: Muhammadiyah, Syarikat Islam dan alIrsyad). Ini adalah faktor dari dalam atau internal di tanah air. Tetapi, dari sisi eksternal, kehadiran NU, langsung atau tidak langsung sebagai bentuk

\footnotetext{
${ }^{4}$ Abdul Halim, Sejarah Perjuangan KH. Abdul Wahab (Bandung: Baru, 1970), h. 12-15

${ }^{5}$ Hanun Asrahah, "Sejarah Pendidikan Islam” (Jakarta: PT.LOGOS, 1999), h.171
} 
resistensi terhadap faham wahabisme di satu sisi dan menguatnya kelompok pembeharuan di Mesir yang dikomandoi oleh Jamaluddin al-Afghani dan Rasyid Ridho. ${ }^{6}$

Sedikit menyinggung sejarah pendidikan NU, Pada Muktamar NU ke-3 (1928), elite NU memprakarsai gerakan peduli pendidikan dengan mengajak para panitia Muktamar merespon kecenderungan naiknya kuantitas dan kualitas pendidikan yang mendorong para Muktamirin sepakat untuk membentuk wadah khusus yang menangani bidang pendidikan yang bernama Hoof Bestur Nahdlatul Oelama (HBNO) yang diketuai oleh Ustadz Abdullah Ubaid, hingga Muktamar NU ke-30 (1999) di Kediri, Lirboyo, Jawa Timur, NU tetap menjadikan sektor pendidikan sebagai pemikiran utama yang mencoba mempertegas kembali posisi bidang pendidikan untuk menjadi prioritas program NU.

\section{B. Epistimologi dan Antologi Nahdlatul Ulama \\ 1) Epistimologi}

Mengenal konsep pendidikan Nahdlatul ulama membahas tentang konsep pendidikan yang ada di pesantren. Sistem pendidikannya merupakan rangkaian dari sub sistem atau unsur-unsur pendidikan yang saling terkait dalam mewujudkan keberhasilannya. Ada tujuan, kurikulum, materi, metode, pendidik, peserta didik, sarana, alat, pendekatan, dan sebagainya. Keberadaan satu unsur membutuhkan keberadaan unsur yang lain, tanpa keberadaan salah satu di antara unsur-unsur itu proses pendidikan menjadi terhalang, sehingga mengalami kegagalan. ${ }^{7}$ Pada dasarnya konsep pendidikan pesantren Nahdlatul Ulama masih bersifat tradisional meskipun sebagian ada yang mengadopsi beberapa metode dari barat dalam proses pembelajaran sehingga adanya pondok pesntren modern yang bermunculan.

\footnotetext{
${ }^{6}$ A. Rubaidi, Radikalisme Islam, Nahdlatul Ulama, Masa Depan Moderatisme Islam di Indonesia, Yogyakarta: Logung Pustaka, 2010, h. 22

${ }^{7}$ Qomar, Epistemologi Pendidikan Islam, 218
} 
Pengaruh pendidikan Barat terhadap pendidikan yang berkembang di hampir semua negara ternyata sangat kuat. Pengaruh ini juga menembus pendidikan Islam, sehingga sistem pendidikan Islam mengalami banyak kelemahan. Untuk mengatasi kelemahan-kelemahan tersebut, para pakar pendidikan Islam dan para pengambil kebijakan dalam pendidikan Islam harus mengadakan pembaharuan-pembaharuan secara komprehensif agar terwujud pendidikan Islam ideal yang mencakup berbagai dimensi. Pada dimensi pengembangan terdapat kesadaran bahwa cita-cita mewujudkan pendidikan Islam ideal itu baru bisa dicapai bila ada upaya membangun epistemologinya. ${ }^{8}$

Epistemologi pendidikan pesantren ini, meliputi; pembahasan yang berkaitan dengan seluk beluk pengetahuan pendidikan pesantren mulai dari hakekat pendidikan pesantren, asal-usul, sumber, metode membangun pendidikan pesantren, unsur, sasaran, macam-macam pendidikan pesantren dan sebagainya. Dalam pembahasan ini epistemologi pendidikan pesantren lebih diarahkan pada metode atau pendekatan yang dapat dipakai membangun ilmu pendidikan pesantren, daripada komponen-komponen lainnya, karena komponen metode tersebut paling dekat dengan upaya mengembangkan pendidikan pesantren, baik secara konsepteual maupun aplikatif.

Secara substansial, salah satu diskursus pesantren tertuju pada kitab kuning. Kitab kuning difungsikan oleh kalangan pesantren sebagai referensi nilai universal dalam menyikapi segala tantangan kehidupan. Karena itu, kitab kuning tetap terjaga. Kitab kuning dipahami sebagai mata rantai keilmuan Islam yang dapat bersambung hingga pemahaman keilmuan Islam masa tabiin dan sahabat hingga sampai pada nabi Muhammad. Oleh sebab itu, memutuskan mata rantai kitab kuning, sama artinya membuang sebagian sejarah intelektual umat.

\footnotetext{
${ }^{8}$ Ibid.249.
} 


\section{2) ONTOLOGI}

Ontologi adalah teori tentang 'ada', yaitu tentang apa yang dipikirkan, yang menjadi obyek filsafat. Menurut Jujun S. Suria sumantri, ontologi terkait tentang hakikat apa yang dikaji, atau jawaban dari "apakah hakikat kenyataan ini sebenar-benarnya? Kajian ontologi mengacu kepada realita. Menurut Imam Barnadib, sebagaimana dikutip oleh Jalaluddin, realita ialah kenyataan, yang seterusnya mengarah kepada masalah kebenaran. Kebenaran akan muncul jika orang telah mampu menarik konklusi bahwa ilmu yang diraih telah nyata. ${ }^{9}$

Dengan demikian landasan ontologi di sini dimaknai sebagai apa yang menjadi dasar berpijak bagi konsep pendidikan dalamorganisasi NU. Landasan itu diadopsi menjadi nilai-nilai yang mengkonstruk sistem pendidikan NU, baik dalam tataran konsep maupun aplikatif. Merujuk pada uraian sebelumnya dapat dilihat landasan yang menjadi dasar pendidikan NU. Pijakannya berasal dari prinsip dasar (Qanun Asasi) NU yang intinya tertuang dalam konsep Ahlussunnah Waljamaah yang dipahami bukan hanya sebagai ketentuan bermazhab secara rigid, tetapi lebih pada sebuah manhaj yang bersifat dinamis.

Karakter pemahaman dinamis terhadap konsep Ahlussunnah Waljamaah tersebut diartikan sebagai perlunya pembaharuan terus-menerus yang harus berlangsung dengan prinsip tawâzun (moderat), ta'âdul (keseimbangan) dan tasâmuh (toleransi). Model pembaharuan seperti ini tertuang dalam kaidah terkenal "mempertahankan tradisi lama yang masih relevan, dan responsif terhadap gagasan baru yang lebih baik dan lebih relevan." Dengan demikian, landasan di atas menegaskan bahwa NU sebagai organisasi telah meletakkan dasar-dasar pendidikan yang selalu siap melakukan upaya rekonstruksi pemahaman terhadap perkembangan dunia pendidikan sehingga tetap relevan dan dapat menjawab tuntutan masa kini dan masa depan. Hal lain yang menarik dari landasan ini adalah semangat adaptasinya terhadap budaya di tengah upaya modernisasi, bukan memusuhi, bahkan secara implisit menyiratkan arti perlunya upaya pemaduan antara keduanya, yang dalam kancah pemikiran Islam disebut new modernisme.

\footnotetext{
${ }^{9}$ Jalaluddin, Filsafat Pendidikan Islam, Jakarta: Kalam Mulia, 2012, h. 123
} 
Sebagaimana diketahui bahwa pemaduan antara tradisi dan modernitas dalam wacana pemikiran Barat senantiasa dipertentangkan akibat pengaruh konsep Barat yang memetakan modernisasi membentur tradisi. Sementara itu pemikir neo-modernis berpandangan bahwa modernisasi merupakan mata rantai dari tradisi, sehingga perlu upaya mengintegrasikan tradisi dengan modernisasi ${ }^{10}$

\section{Konsep Pendidikan}

Nahdlatul Ulama dalam konsep pendidikan merupakan manifestasi dari kehidupan keagamaan, sosial, dan budaya dari para Kiai. Dengan demikian pesantren, Nahdlatul Ulama dan para Kiai sebagai sentral selalu mengaitkan diri dalam membentuk masyarakat. Kekompakan itu merupakan lembaga yang mempunyai peran kuat dalam perkembangan dan masyrakat Islam pada kualitas sumberdaya manusia harus ditingkatkan melalui institusi yang bergerak dalam bidang pendidikan. Pertama, pendidikan Islam memberikan pengaruh terhadap sosio-kultural, dalam arti memberikan wawasan filosofi, arah pandangan motivasi perilaku, dan pedoman perubahan sampai terbentuknya suatu realitas sosial baru, Kedua, pendidikan Islam di pengaruhi oleh perubahan sosial dan lingkungan sosio-kulural dalam penentuan sistem pendidikan.

Pesantren adalah model pendidikan yang sama tuanya dengan Islam di Indonesia, jika dilihat dari keberadaanya, pesantren merupakan institusi pendidikan dan dakwah agama Islam. Ia lahir ditengah-tengah masyarakat yang belum mengenal sekolah dan universitas. ${ }^{11}$ Tidak dapat dipungkiri bahwa pesantren mempunyai andil besar dalam mencerdaskan kehidupan bangsa. Dalam wacana ini, menjalankan fungsi pendidikan merupakan tugas pokok dari semua pesantren. Sementara itu fungsi agama dalam kehidupan diharapkan menjadi faktor pencerahan bagi kehidupan manusia. Pencerahan yang menumbuhkan kedamaian, keadilan, demokrasi, moralitas, dan pemenuhan hak dasar manusia serta tegaknya adiluhur dalam menghantarkan manusia kepintu gerbang rahmat.

\footnotetext{
${ }^{10}$ Mujamil Qomar, Pesantren dari Transformasi Metodologi Menuju Demokratisasi Institusi , Jakarta: Erlangga, 2006, h. 74.

${ }^{11}$ Dr. Lunch Castels, Aris Arief Mundayat, Membangun Budaya Kerakyatan, (yogyakarta: Titan Ilahi Press, 1997) h.200
} 
Pendidikan NU mempunyai dua ciri yang esensial; 1). Al-I'timad alannafsi (berdikari), dan 2). Fil Ijtimaâiyah (memasyarakat), artinya dihidupi oleh masyarakat. Madrasah atau pesantren itu didirikan oleh masyarakat dan dibiayai sendiri oleh masyarakat. Ketika masyarakat mau belajar atau mau menyekolahkan anaknya di pesantren atau madrasah, mereka hanya ditunjukkan tempatnya oleh Kiai, kemudian mereka membangun kamar sendiri. Hal itu sekarang bergeser pesantren atau madrasah tidak berdikari, mereka juga mencari sumbangan ke pemerintah. Wali santri sekarang tidak otomatis menyumbang kecuali ada tarikan dari pihak sekolah. Jadi tidak ada kesukarelaan seperti dulu, kalau wali santri menitipkan anaknya ke pesantren maka bangunan pesantren menjadi tanggung jawab wali santri.

Sebagaimana yang dikutip La Ode Ida, menyatakan bahwa basis NU adalah pesantren suatu lembaga pendidikan yang dikelola untuk mengembangkan dan mewariskan ajaran ahlusunnah waljama'ah (aswaja) dengan penekanan pada metode pendidikan tradisional berupa pengulangan dan memorisasi sumber-sumber ajaran agama yang menjadi standarnya. Salah satu sumber literaturnya yang sangat menonjol adalah "kitab kuning" yakni buku-buku yang berbahasa Arab karya para penulis Muslim periode pertengahan, yang isinya menyangkut sekitar jurisprudensi (fikih), tauhid (hakekat Allah), hadits , tasawuf dan bahasa Arab. ${ }^{12}$

Ciri khas ajaran Ahlusunnah Wal Jamâ'ah (Aswaja), yang menjadi garis perjuangan NU bersumber pada Al-Qur'an, Sunnah, Ijma' (keputusan para ulama sebelumnya), dan Qiyas (kasus-kasus yang belum ada dalam dalam al-Qur'an dan Hadist, disamakan dengan masalah yang sudah ada nashnya karena persamaan Illatnya). Secara terperinci dalam konteks aplikasinya, KH Mustafa Bisri menyebutkan bahwa terdapat tiga substansi ajaran; Pertama, dalam bidang hukum Islam, menganut salah satu ajaran dari empat madzhab

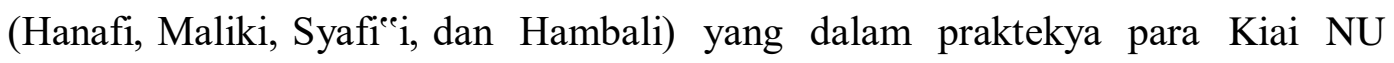
menganut kuat madzhab Syafieci. Kedua, dalam soal tauhid (ketuhanan) 2004), h. 1

\footnotetext{
${ }^{12}$ La Ode Ida, NU Muda Kaum Progresif dan Sekularisme Baru, (Jakarta: Erlangga,
} 
menganut ajaran Imam Abu Hasan al-Asyeari dan Imam Abu Mansur alMaturidi. Ketiga, dalam bidang tasawuf menganut dasar dasar ajaran Imam Abu Qasim al-Junaidi.

\section{Pembaruan Konsep Pendidikan Nahdlotul Ulama}

Ada usaha pembaruan pendidikan Islam, terutama di pedalaman Jawa. pada umumnya diselenggarakan dengan cara sangat sederhana, baik dalam bentuk pesantren lama maupun madrasah diniyah, yang dari segi sistem dan kelembagaannya dianggap tidak dapat diandalkan untuk memenuhi kebutuhan perubahan zaman. Dengan bertahap dan tetap menjaga kontinuitas tradisi, NU melalui Bagian Ma'arifnya, memulai usaha pembaruan pendidikannya sejak awal 1930-an, melalui serangkaian koreksi dan inovasi agar pendidikan Islam dapat memainkan fungsi sosialnya secara maksimal.

Aspek-aspek yang sifatnya substansial mendapatkan perhatian tanpa mengabaikan aspek-aspek yang bersifat teknis-metodik. Hal paling mendasar adalah menyangkut teologi pendidikannya, yang lebih menekankan penggunaan konsep 'manusia dinamis'. Dimaksud manusia dinamis di sini adalah manusia yang dalam sikapnya rasional, bertanggung jawab, selalu berprakarsa dan melakukan ikhtiar; bergerak ke depan, berubah dan berkembang menuju ke tingkat yang lebih sempurna (kamīl). Citra manusia dinamis ditandai dengan prestasinya yang bermakna dan berguna, baik bagi dirinya sendiri maupun orang lain serta lingkungannya, dari waktu ke waktu, selama proses menuju kamil. Jumlah total dari prestasi tersebut akan menunjukkan tingkat kesempurnaan sebagai manusia. Jadi, manusia dinamis identik dengan maju, dalam arti tidak bisa menerima kondisi stagnan (humūl) atau berhenti (jumūd), dan senantisa berorientasi ke depan (optimisme).

Bertolak dari sini, pembaruan dilanjutkan dengan mengadakan semacam apa yang disebut dengan reaktualisasi dan reposisi. ${ }^{13}$ Hal tersebut agar lembaga pendidikan Islam dapat menjalankan fungsinya secara maksimal

\footnotetext{
${ }^{13}$ H.A.R. Tilaar, Paradigma Baru Pendidikan Nasional, (Jakarta, Reneka Cipta, 2004),
} hal. 172 
dalam rangka pencapaian tujuan pendidikan yang telah ditetapkan. Reaktualisasi adalah upaya menghidupkan dan menggerakkan kembali nilainilai positif yang sejak dulu dimiliki lembaga pendidikan Islam, dan cocok dengan kondisi modern, sambil membenahi kelemahan-kelemahan yang ada di dalamnya, dengan mengikut-sertakan partisipasi masyarakat secara optimal dalam penyelenggaraannya. Sedangkan, reposisi dimaksudkan sebagai upaya mengatur atau merumuskan kembali posisi lembaga pendidikan Islam bukan sekadar sebagai lembaga pengajaran ilmu-ilmu agama (tafaqquh fì al-dìn), tetapi sekaligus juga berbagai ilmu pengetahuan umum dan keterampilan (teknologi), serta sebagai lembaga pendidikan pribumi (Islam) yang mementingkan tegaknya nilai-nilai demokrasi, toleransi, pluralisme, moral budi pekerti; memperkuat iman-takwa, dan memupuk kerja sama dan tolong menolong antar sesama komponen bangsa dalam suasana kompetisi menghadapi tuntutan kehidupan modern.

Pembaruan pendidikan NU adalah cermin kemodernan para pendidik pesantren yang berusaha membawa warganya kepada cara pandang baru di lapangan pendidikan, sebagai sarana maksimalisasi aktifitas pendidikan pengajaran Islam di kurun modern, guna melengkapi system kelembagaan pendidikan tradisional (pesantren) yang ada, karena telah mengalami pelapukan akibat dimakan usia. Hal ini pada gilirannya terbukti menjadi tenaga penggerak bagi perbaikan mutu penyelenggaraan pendidikan masyarakat bawah dalam rangka memasuki kemajuan dan turut mengisi serta memperkaya sistem pendidikan nasional.

Salah satu model pembelajaran yang tepat dan bisa berkembang dan kreatif dalam konsep Nahdlatul ulama sebenranya sudah di cantumkan dalam kitab karya KH Hasim Asyari. Metode itu di satupadukan sehingga model pembelajaran akan berkembang dan tidak stagnan serta mengatasi problem ketika santri atau peserta didik kesulitan dalam memahami sebuah materi apa yang disampaikan oleh guru. 
Metode itu antara lain adalah hafalan, metode ceramah, metode diskusi metode Tanya jawab dan metode Tahdzib wa targhib (menasihati dan menegur).

\section{Metode hafalan}

Mentasih (memperbaiki/menyimakkan/menyetorkan hafalan) terlebih dahulu di hadapan pendidik atau temanya yang diyakini kepintaranya. Seperti yang dirisalahkan beliau :

Peserta didik apabila mempunyai niat menghafal suatu teks atau bacaan, sebaiknya ia mentahshih (memastikan teks kebenaran teks itu) pelajaran yang dibacanya dihadapan guru atau orang yang memahami bacaan tersebut. Sehingga melalui upaya tersebut diharapkan ia terhindar dari kesalahan-kesalahan redaksional atau substansional teks. Kemudian apabila iya telah menghafal teks tersebut hendaknya ia senantiasa menjaga dan mengokohkan hafalanya itu dengan melakukan pengulangan secara rutun. ${ }^{14}$

2. Kemudian metode ceramah, dalam metode ini menjadi perhatian

KH. Hasyim Asyari dengan ketentuan sebagai berikut :

a) Menghindari penjelasan yang terlalu panjang sehingga membosankan, sebaliknya juga jangan terlalu ringkas sehingga substansi dari materi tidak tersampaikan. Hal ini nampak dalam tulisan beliau :

Menghindari penjelasan yang terlalu panjang sehingga akan membosankan para hadirin termasuk juga meringkas suatu penjelasan dengan amat ringkas sehingga banyak hal yang luput dari penjelasan yang seharusya disampaikan. Guru dituntut memahami situasi dan kondisi para siswanya."

b) Tidak terlalu tergesa-gesa dalam menjelaskan sehingga penjelasanya dapat disimak dan dipikirkan oleh siswanya. Hal ini nampak dalam tulisan beliau: "Hendaknya tidak terlalu cepat (tergesa-gesa) dalam menyampaikan penjelasan, akan tetapi seyogyanyaguru menyampaikan dengan pelan-pelan sehingga penjelasanya akan dapat disimak dan dipikirkan baik-baik oleh orang-orang yang mendengarnya." Apabila materi yang disampaikan lebih dari satu pembahasan, mulai dengan materimateri yang penting

${ }^{14}$ KH. Hasyim Asy’ari, Adab Al-‘Alim Wa al-Muta'allim (Jombang: Maktabah At Turas Al Islam, 1415H), 46. 
3) Metode diskusi, sebagimana yang diungkapkan KH. Hasyim Asyari dalam perkatanya : Peserta didik hendaknya mendiskusikan problematika yang update (waqi'iyah) bersama teman-temanya untuk menarik definisi, mendasarkanya dan mencari faidahnya (makna tersembunyi) pembiasaan.

4) Metode Tahzib wa Targib (menasihati dan menegur) dengan baik terhadapanak didik yang bandel. Sebagaimana yang diungkapkan beliau dalam perkatanya :

Memberi peringatan tegas terhadap siswa yang melakukan hal-hal di luar batas etika yang semestinya dijaga disaat mereka berada di dalam majlis. Misalnya mengabaikan peringatan dan petujuk, melakukan hal-hal yang tidak bermanfaat, bersikap tidak baik pada siswa lainya, tidak menghargai kepada orang yang lebih tua, tidur, ngobrol, tertawa, bercanda dengan salah satu siswa yang lainya.

5) Metode Tanya-jawab, Sebagaimana yang diungkapkan beliau dalam perkatanya, seperti berikut: Senantiasa menanyakan pelajaran yang sulit, minta untuk difahamkan atas pelajaran yang tidak bisa difahaminya dengan bahasa yang lembut dan sopan.

Dalam proses pembelajaran, KH. Wahid Hasyim membangun suasana dialogis. Namun meskipun demikian, beliau menggaris bawahi hal-hal yang perlu diperhatikan oleh seorang pelajar, yaitu moralitas dan etika dalam menghormati dan menghargai seorang ulama. Terutama pada lingkungan pesantren yang mempunyai gaya tersendiri dalam mendidik para santri. Kyai adalah simbol dari moralitas, yang kedudukanya lebih dari sekedar ulama. Karena, Kyai dianggap tidak hanya mengajarkan ilmu, tetapi juga mengajarkan moralitas. ${ }^{15}$ Disinilah kenapa para santri sangat menghargai Kyai

${ }^{15}$ Zuhairi Misnawi, Hadratussyaikh Hasyim Asy'ari, Moderasi, Keutamaan dan Kebangsaan (Jakarta: Kompas, 2010), 230 


\section{KESIMPULAN}

Pendidikan Islam memberikan pengaruh terhadap sosio-kultural, dalam arti memberikan wawasan filosofi, arah pandangan motivasi perilaku, dan pedoman perubahan sampai terbentuknya suatu realitas sosial baru. Selian itu, pendidikan Islam di pengaruhi oleh perubahan sosial dan lingkungan sosio-kulural dalam penentuan sistem pendidikan Pesantren.

Pembaruan pendidikan NU adalah cermin kemodernan para pendidik pesantren yang berusaha membawa warganya kepada cara pandang baru di lapangan pendidikan, sebagai sarana maksimalisasi aktifitas pendidikan pengajaran Islam di kurun modern. Untuk melengkapi system kelembagaan pendidikan tradisional, pembaharuan dalam pembelajaran di kalangan masyarakat baik sekolah formal maupun pondok pesantren mengalami kemajuan dalam metode pembelajaran tidak hanya mengunakan metode hafalan saja dalam belajar namun di sertakan metode ceramah, metode diskusi, metode Tahzib wa Targib (menasihati dan menegur), metode Tanya-jawab, sehingga metode pembelajaran bagi siswa ataupun santri tidak lagi menggunakan metode hafalan, saja tetapi mengkombinasi metode tersebut sesuai apa yang di pelajari guna untuk mempermudah proses pembelajaran yang sedang berlangsung dan para siswa dan santri tidak bosen dalam pembelajaran atau tidak monoton sehingga pembelajran tersebut aktif. 


\section{DAFTAR PUSTAKA}

A. Rubaidi, Radikalisme Islam, Nahdlatul Ulama, Masa Depan Moderatisme Islam di Indonesia, Yogyakarta: Logung Pustaka, 2010.

A. Malik Fadjar, Reorientasi Pendidikan Islam, Jakarta, Fajar Dunia, 1999.

Abdul Halim, Sejarah Perjuangan KH. Abdul Wahab, Bandung, Baru, 1970.

Direktorat Jenderal Kelembagaan Agama Islam Departemen Agama, Sejarah Madrasah: Pertumbuhan, Dinamika, dan Perkembangannya di Indonesia. Jakarta, 2004.

Dr. Lunch Castels, Aris Arief Mundayat, Membangun Budaya Kerakyatan, Yogyakarta: Titan Ilahi Press, 1997

H M Thoyyib, IM dan Endang Turmudzi, Islam Ahlussunnah Waljama'ah di Indonesia: Sejarah, Pemikiran dan Dinamikaa Nahdlatul Ulama, Cetakan kedua. Jakarta: Pustaka Ma’arif, 2007.

H.A.R. Tilaar, Paradigma Baru Pendidikan Nasional, Jakarta, Reneka Cipta, 2004 Hanun Asrahah,, Sejarah Pendidikan Islam, Jakarta, PT.LOGOS, 1999.

Jalaluddin, Filsafat Pendidikan Islam, Jakarta, Kalam Mulia, 2012.

La Ode Ida, NU Muda Kaum Progresif dan Sekularisme Baru, Jakarta: Erlangga, 2004.

Mujamil Qomar, Pesantren dari Transformasi Metodologi Menuju Demokratisasi Institusi , Jakarta: Erlangga, 2006. 